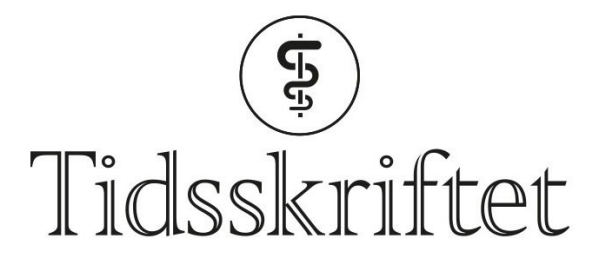

DEN NORSKE LEGEFORENING

\title{
Epikutan immunterapi mot peanøttallergi
}

FRA ANDRE TIDSSKRIFTER

PETTER MORTEN PETTERSEN

Tidsskriftet

Daglig applikasjon av peanøttproteiner på huden kan desensibilisere barn med peanøttallergi.

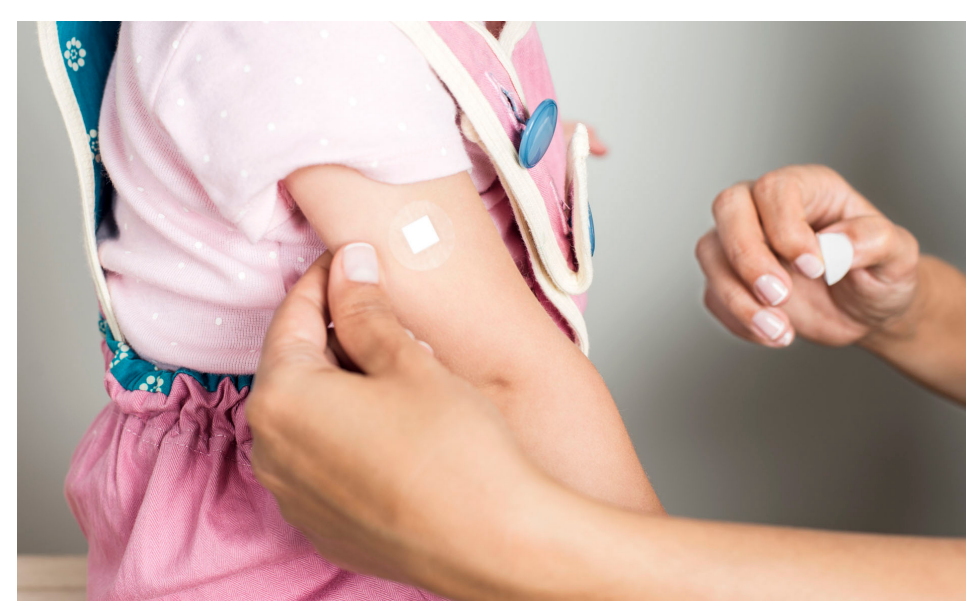

Illustrasjonsfoto: simarik/iStock

Allergi mot peanøtter er en vanlig form for matvareallergi. Studier fra USA og europeiske land har vist en forekomst på 0,5-2 \% av befolkningen.

I en internasjonal multisenterstudie ble 356 peanøttallergiske barn i alderen 4-11 år randomisert til epikutan immunterapi, dvs. daglig epikutan applikasjon av peanøttproteiner, eller placebo (1). Perorale provokasjonstester med pean $ø$ ttproteiner ble gjort før og etter 12 måneders behandling, der man registrerte laveste mengde peanøttprotein som utløste objektive tegn eller symptomer på en sensitivitetsreaksjon. Barna ble definert som respondere hvis forskjellen i dette dosenivået var av en viss størrelse. Responsraten etter epikutan immunterapi og placebo var hhv. 35,3\% og 16,3\% (p < o,oo1). Forskjellen var likevel mindre enn det som på forhånd var definert som en positiv effekt.

- Resultatet fra denne studien er ikke spesielt overraskende ut fra det som tidligere er publisert om epikutan immunterapi mot peanøttallergi, sier Geir Håland, som er overlege ved Regionalt senter for astma, allergi og overfølsomhet ved Oslo universitetssykehus.

- Effekten var begrenset, men behandlingen ga få bivirkninger, selv om det var enkelte tilfeller av anafylaksi. Lengre behandlings- og observasjonstid kunne kanskje gitt flere 
respondere. Epikutan immunterapi er desensibiliserende og ikke-kurerende behandling. Det betyr at langvarig, sannsynligvis livslang, behandling er nødvendig.

LITTERATUR:

1. Fleischer DM, Greenhawt M, Sussman G et al. Effect of epicutaneous immunotherapy vs placebo on reaction to peanut protein ingestion among children with peanut allergy. JAMA 2019;321: 946-55. [PubMed][CrossRef]

Publisert: 3. mai 2019. Tidsskr Nor Legeforen. DOI: 10.4045/tidsskr.19.0250

(C) Tidsskrift for Den norske legeforening 2020. Lastet ned fra tidsskriftet.no 